УДК 342.951

DOI https: / / doi.org/10.32837 / yuv.v0i5.2009

\author{
А. Гапонов, \\ заступник голови \\ Апеляційного суду Донецької області (м. Бахмут)
}

\title{
ЩОДО ВДОСКОНАЛЕННЯ СИСТЕМИ ФОРМУВАННЯ СУДДІВСЬКОГО КОРПУСУ АПЕЛЯЦІЙНИХ СУДІВ В УКРАЇНІ
}

Важливим компонентом авторитетної та незалежної судової влади в державі $є$ ефективна система формування суддівського корпусу, адже саме професійний суддя має бути гарантом реальної можливості захисту прав і законних інтересів особи, громадянина.

Незважаючи на суспільну важливість стабільного функціонування судової влади, що забезпечується, в тому числі, наявністю достатньої кількості штатних професійних суддів, останніми роками в Україні тенденція відтоку кадрів суддівського корпусу викликає обгрунтовану стурбованість.

Аналізом огляду даних про стан здійснення правосуддя за 20152019 роки встановлено стійку тенденцію до зниження кількості суддів, що наділені повноваженнями щодо здійснення правосуддя. Це однаково стосується як суддів місцевих, так і апеляційних судів $[1 ; 2]$.

Зокрема, станом на 01 січня 2020 року ситуація з укомплектуванням посад в апеляційних судах виглядає таким чином:

- визначена штатна чисельність суддів загальних апеляційних судів 964, з них фактично працює 640 суддів, 605 з яких - із повноваженнями, a 32 не пройшли кваліфікаційне оцінювання;

- визначена штатна чисельність суддів господарських апеляційних судів - 218, з них фактично працює 169 суддів, 160 з яких - із повнова- женнями, а 20 не пройшли кваліфікаційне оцінювання;

- визначена штатна чисельність суддів адміністративних апеляційних судів - 257, з них фактично працює 203 судді, 195 з яких - із повноваженнями, а 16 не пройшли кваліфікаційне оцінювання [3].

3 викладених статистичних даних 3'ясовано, що відсоток суддів, які наділені повноваженнями щодо здійснення правосуддя, в загальних апеляційних судах складає $63 \%$, в господарських апеляційних судах $73 \%$, в адміністративних апеляційних судах - $76 \%$.

За повідомленням Голови Вищої Ради правосуддя, станом на 12 лютого 2020 року в Україні залишаються незаповненими близько 2 тисяч суддівських посад [4].

3 урахуванням викладеного, нагальність і гострота проблеми формування суддівського корпусу апеляційних судів в Україні нині вкрай актуальна.

Вітчизняні науковці, зокрема I.В. Назаров, М.Г. Мельник, В.М. Мартиненко, I.Є. Марочкін, С.В. Ківалов, А.О. Малихіна, досліджували у своїх працях деякі аспекти формування суддівського корпусу в Україні, проте в умовах безперервної судової реформи й оновленого правового регулювання цих процедур постає необхідність його актуального дослідження.

Деякі основні елементи процедури формування суддівського корпусу 
врегульовано на рівні Конституції України.

Частиною 2 статті 127 Конституції України визначаються вимоги, що $є$ мінімальними для обіймання посади судді. Відповідно до ї̈ змісту, на посаду судді може бути призначений громадянин України не молодший тридцяти й не старший шістдесяти п'яти років, який має вищу юридичну освіту й стаж професійної діяльності у сфері права щонайменше п'ять років, є компетентним, доброчесним і володіє державною мовою. Законом можуть бути передбачені додаткові вимоги для призначення на посаду судді [5].

Статтею 128 закріплено, що призначення на посаду судді здійснюється Президентом України за поданням Вищої ради правосуддя в порядку, встановленому законом. Згаданий порядок розкривається в спеціальному Законі України.

У результаті аналізу змісту статті 81 Закону України «Про судоустрій і статус суддів» доходимо висновку, що процедуру формування суддівського корпусу апеляційних судів можна умовно поділити на два основних етапи, а саме процедуру проведення конкурсу на посаду судді апеляційного суду й процедуру призначення кандидата на посаду судді [6].

Детально розглянемо окремі аспекти цих процедур та утворювані в процесі проблемні питання їхньої практичної реалізації.

Згідно із чинним законодавством, органом, що безпосередньо уповноважений проводити процедуру конкурсу на посаду судді апеляційного суду, $€$ Вища кваліфікаційна комісія суддів України, яка має статус державного колегіального органу суддівського врядування, який на постійній основі діє в системі правосуддя в Україні (надалі - ВККСУ). Вона має офіційний вебсайт і офіційний друкований орган, що $є$ офіційними джерелами про їі роботу.
Відповідний конкурс на зайняття вакантної посади судді апеляційного суду проводиться на підставі Положення про проведення конкурсу на зайняття вакантної посади судді, що містить декілька основних етапів [7].

Так, відповідний конкурс оголошується на підставі рішення BKKCУ. $\mathrm{V}$ рішенні визначається найменування судів, кількість вакантних посад, порядок і строки подання заяви для участі в конкурсі, перелік документів, що додаються до заяви, й вимоги до них, умови його проведення, дата, час і місце проведення конкурсу, повноваження палат (колегій) ВККСУ щодо проведення конкурсу, інша необхідна інформація. Оголошення про проведення конкурсу ВККСУ розміщує на своєму офіційному вебсайті й вебпорталі судової влади й публікує у визначених друкованих засобах масової інформації не пізніше як за місяць до дня проведення конкурсу.

Кандидат на посаду судді, який перебуває в резерві на заміщення вакантних посад суддів, або який $€$ суддею, звертається до ВККСУ в порядку, визначеному рішенням про оголошення конкурсу, й подає заяву про участь у конкурсі з переліком відповідних документів.

Крім цього, також вимагаються документи, що підтверджують дотримання однієі 3 кваліфікаційних вимог, визначених частиною першою статті 28 Закону, а саме: відомості про стаж роботи на посаді судді не менше п'яти років, або підтвердження наукового ступеня у сфері права й стаж наукової роботи у сфері права щонайменше сім років, або підтвердження досвіду професійної діяльності адвоката, в тому числі щодо здійснення представництва в суді й / або захисту від кримінального обвинувачення щонайменше сім років, або наявність сукупного стажу (досвіду) роботи (професійної діяльності) відповідно до вимог, визначених попередніми переліченими пунктами, щонайменше сім років. 
На етапі подання документів для участі в конкурсі виникають певні проблемні питання практичного характеру.

Зокрема, розділом III Положення про проведення конкурсу на зайняття вакантної посади судді передбачено форму подання документів, а саме паперову, під якою розуміється подання документів кандидатом особисто до ВККСУ, й електронну, тобто через офіційний вебсайт ВKKСУ.

Необхідно зазначити, що електронна форма подання документів кандидатом для допуску до кваліфікаційного оцінювання не передбачена вищезгаданим Законом.

Незважаючи на це, в оголошенні ВККСУ про конкурс від 09 серпня 2019 року на зайняття 346 вакантних посад суддів в апеляційних судах визначено ще одну форму надання документів для кандидатів для допуску до кваліфікаційного оцінювання, а саме за допомогою поштового зв'язку [8]. Необхідно зазначити, що подання документів для участі в конкурсі з метою проходження кваліфікаційного оцінювання за допомогою поштового зв'язку не передбачено ані вищезгаданим Законом, ані Положенням про проведення конкурсу на зайняття вакантної посади судді.

Крім цього, незрозумілою є вимога до кандидата на посаду судді, який $€$ суддею, про подання ним окремо декларації доброчесності судді, хоча вона входить до переліку документів, визначених пунктами 2-13 частини першої статті 71 Закону України «Про судоустрій і статус суддів». До того ж зазначена декларація заповнюється на офіційному вебсайті ВККСУ й подається суддею щорічно в період з 1 по 31 січня.

Також установлено, що умовами про проведення конкурсу, всупереч приписам частини 3 статті 71 Закону України «Про судоустрій і статус суддів», розширено перелік матеріалів, що подаються для участі в конкурсі. Так, підпунктом 16 пункту 7 згаданих умов визначено необхідним подання компакт-диску зі сканованими копіями документів, визначених Умовами, й інформацією про кандидата. Вказана вимога $є$ незрозумілою, оскільки оцифровувати надані кандидатом на посаду судді документи $€$ компетенцією відповідальної особи в розумінні пункту 3.7 вищезгаданого Положення про проведення конкурсу на зайняття вакантної посади судді.

Окрім цього, на офіційному сайті відсутні будь-які документи ВККСУ 3 питань упорядкування та вимог із технічного захисту під час роботи 3 інформацією, що міститься на цих носіях, яка є конфіденційною, оскільки містить персональні дані кандидатів на посаду.

3 урахуванням викладеного, зважаючи на те, що скановані версії документів кандидата необхідні для формування цифрового суддівського (кандидатського) досьє, це питання можливо розв'язати шляхом або внормування цієї вимоги в законі, або iï виключення з умов про проведення конкурсів на вакантні посади суддів надалі.

Таким чином, вбачається доцільним доповнити частину 1 статті 71 Закону України «Про судоустрій і статус суддів» абзацом 15 такого змісту: «14) електронний носій (компакт-диск або флеш-накопичувач) зі сканованими копіями документів, визначених Умовами, й інформацією про кандидата. Скановані копіі документів не повинні містити персональні дані кандидата на посаду в розумінні Закону України «Про захист персональних даних». 3 урахуванням запропонованих змін необхідно внести кореспондуючі зміни до пункту 3.7 вищезгаданого Положення про проведення конкурсу.

У процедурі призначення кандидата на посаду судді апеляційного суду відіграє важливу роль не лише ВККСУ, а й Вища рада правосуддя, до повноважень якої належить розгляд рекомендації ВККСУ щодо призна- 
чення кандидата на посаду судді за результатами проведеного конкурсу.

Розгляд Вищою радою правосуддя рекомендації Кваліфікаційної комісії здійснюється відповідно до статті 36 Закону України «Про Вищу раду правосуддя» [9].

Відповідно до вказаної норми, а також Глави 10 Регламенту Вищої ради правосуддя, попередній розгляд рекомендації, наданої кандидату Кваліфікаційною комісією, здійснює доповідач, який готує висновок, що передається до відповідного структурного підрозділу секретаріату Ради для формування порядку денного Вищої ради правосуддя [10].

Рішення про внесення подання Президентові України про призначення судді на посаду вважається ухваленим, якщо за нього на засіданні проголосувало не менше чотирнадцяти членів Ради. Рішення про внесення подання підписує головуючий на засіданні одноособово.

Відповідно до пункту 5.8. Регламенту Вищої ради правосуддя, засідання Ради в пленарному складі, на якому розглядається питання щодо внесення подання про призначення судді на посаду, повноважне, якщо в ньому беруть участь не менше чотирнадцяти членів Ради.

Окрім того, частина 19 статті 79 Закону України «Про судоустрій і статус суддів» зазначає, що Вища рада правосуддя може відмовити у внесенні Президентові України подання про призначення судді на посаду з підстави наявності обгрунтованого сумніву щодо відповідності кандидата критерію доброчесності чи професійної етики або інших обставин, які можуть негативно вплинути на суспільну довіру до судової влади у зв'язку з таким призначенням. Ці підстави Вища рада правосуддя визначає, керуючись власною оцінкою обставин, пов'язаних із кандидатом на посаду судді, та його особистих якостей.

Таким чином, за умови, що в пленарному засіданні бере участь чотир- надцять членів Ради, позитивне рішення про внесення подання Президентові України про призначення судді на посаду може бути прийнято ними лише одностайно, що, на думку автора, досить суттєво обмежує можливості претендента на отримання посади судді через можливе упереджене ставлення до нього з боку хоча б одного із членів Вищої ради правосуддя.

Зурахуванням викладеного, з метою сприяння демократизації цього останнього етапу, під час якого досліджуються відомості щодо кандидата, які можуть викликати суб'єктивне ставлення до нього, пропонується внести зміни до частини 3 статті 37 Закону України «Про Вищу раду правосуддя», змінивши слова «<..> не менше чотирнадцяти членів Вищої ради правосуддя» на «<...> не менше двох третин від присутніх членів Вищої ради правосуддя». Відповідно, абзац 2 пункту 10.5 Регламенту Вищої ради правосуддя необхідно змінити, виклавши його в такій редакції: «Рішення про внесення подання Президентові України про призначення судді на посаду вважається ухваленим, якщо за нього проголосувало не менше двох третин від присутніх членів Ради».

Підсумовуючи викладене необхідно підкреслити, що вдосконалення, передусім нормативне, системи формування суддівського корпусу апеляційних судів в Україні сприятиме демократизації та прозорості процесів проведення конкурсів на посаду суддів апеляційних судів, призначення кандидатів на посаду судді апеляційного суду.

У статті викладено актуальну проблему необхідності вдосконалення нормативного регулювання процедури формування суддівського корпусу апеляційних судів України у зв'язку зі зниженням кількості суддів, щзо мають повноваження для здійснення правосуддя. 
Розглянуто окремі проблемні аспекти здійснення процедури проведення конкурсу на посаду судді апеляційного суду, а також процедури призначення на посаду суддi.

Запропоновано розв'язання проблемних питань нормативної регламентації діяльності Вищої кваліфікаційної комісї суддів України на етапі подання документів для участі в процедурі проведення конкурсу на посаду судді апеляційного суду, зокрема внесення відповідних змін до Закону України «Про судоустріи $i$ статус суддів», a також до Положення про проведення конкурсу на зайняття вакант-

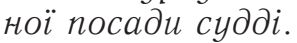

Під час дослідження проаналізовано деякі процедурні аспекти розгляду членами Вищої ради правосуддя рекомендацій, наданих Вищою кваліфікаційною комісією суддів Украйни кандидату на посаду судді за результатами проведеного конкурсу. Установлено, що з урахуванням невизначених критеріїв доброчесності до посади суддi або інших обставин, які можуть негативно вплинути на суспільну довіру до судової влади у зв'язку з призначенням кандидата на посаду судді, вимога про голосування чотирнадияяти членів Вищої ради юстиціі в разі такої ж мінімально допустимої для правоможного пленарного засідання кількості членів $\epsilon$ занадто суворою. Тому з метою демократизаціï изього етапу запропоновано внести відповідні зміни до Закону України «Про Вищу раду правосуддя» та до Регламенту Вищої ради правосуддя щодо знинення мінімальної кількості необхідних голосів членів Вищої ради правосуддя, необхідних для ухвалення рішення про внесення подання Президентові України про призначення кандидата на посаду.

Ключові слова: судова влада, суддівський корпус, призначення на посаду судді, функції Вищої кваліфі- каційної комісії суддів України, Вища рада правосуддя.

\section{Gaponov A. Improvement of the system of formation of the judicial corps of courts of appeal in Ukraine \\ The article highlights the urgent} problem of the need to improve the regulation of the procedure for forming the judicial corps of Courts of Appeal of Ukraine because of the reduction of the number of judges with the authority to administer justice.

Particular problematic aspects of the competition procedure for the position of a judge of the Court of Appeal, as well as the procedure for appointment to the position of a judge are considered.

The solution of problematic issues of normative regulation of the High Qualification Commission of Judges of Ukraine at the stage of submitting documents for participation in the competition for the position of a judge of the Court of Appeal, including amendments to the Law of Ukraine "On Judiciary and Status of Judges" and the Regulations to fill the vacant position of a judge.

During the research, some procedural aspects of consideration by the members of the High Council of Justice of the recommendations provided by the High Qualification Commission of Judges of Ukraine to the candidate for the position of a judge based on the results of the competition were analyzed.

It is established that taking into account the uncertain criteria of integrity to the position of a judge or other circumstances that may adversely affect public confidence in the judiciary in connection with the appointment of a candidate for the position of judge, the requirement to vote for fourteen members of the High Council of Justice competent plenary meeting the number of members is too strict. Therefore, in 
order to democratize this stage, the amendments to the Law of Ukraine "On the High Council of Justice" and the Rules of Procedure of the High Council of Justice are proposed to reduce the minimum number of members' of the High Council of Justice votes required for submitting a proposal for the President of Ukraine on the appointment of a candidate for the position of judge.

Key words: judicial branch, judiciary, appointment of judges, High Qualification Commission of Judges of Ukraine's functions, High Council of Justice.

\section{Література}

1. Огляд даних про стан здійснення правосуддя у 2016 році. Офіційний сайт судової влади. URL: https: / / court.gov.ua/ userfiles / file / DSA / DSA_2017_all_docs / TRAVEN_17/ogl_2016_copy.pdf (дama звернення: 20.08.2020).

2. Список судів, в яких кількість суддів, що не здійснюють правосуддя (у зв'язку із закінченням п'ятирічного строку повноважень, досягненням суддею 65-річного віку та з нескладенням присяги судді) складає $50 \%$ $i$ більше відсотків станом на 12.10.2016. Офіційний сайт вищої кваліфікаційної комісії суддів України. URL: https:// vkksu.gov.ua/ua/oblik-posad-suddiw / spisok-sudiw-w-iakich-kilkist-suddiwshtcho-nie-zdijsniuiut-prawosuddia-uzwiazku-iz-zakintchienniam-piatiritchnogostroku-pownowazien-dosiagnienniamsuddieiu-65-ritchnogo-wiku-ta-znieskladienniam-prisiagi-suddi-skladae-50i-bilshie-widsotkiw-stanom-na-1) (Jama звернення: 13.08.2020).

3. Про стан забезпечення незалежності суддів України : Щорічна доповідь за 2019 рік : затв. рішенням Вищої ради правосуддя № 933/0/15-20 від 09 квітня
2020 р. Офіщійний сайт Вищої ради правосуддя. URL: https://hcj.gov.ua/sites / default/files / field/file/shchorichna_ dopovid_za_2019_rik.pdf (даma звернення: 09.09.2020.

4. В Україні відкриті близько двох тисяи вакансій суддів - голова ВРП. Укрінформ : вебсайт. URL: https:// www.ukrinform.ua / rubric-society / 2874873-v-ukraini-vidkriti-blizko-dvohtisac-vakansij-suddiv-golova-vrp.html (дата звернення: 14.08.2020).

5. Конституиія України: Закон України від 28 червня 1996 р. № 254к/96-ВР / Верховна Рада України. Відомості Верховної Ради України. 1996. № 30. Ст. 141.

6. Про судоустрій $i$ cтатус суддів : Закон України від 02 червня 2016 р. № 1402-VIII / Верховна Рада України. Голос України. 16 липня 2016 р. № 132-133.

7. Положення про проведення конкурсу на зайняття вакантної посади судді : затв. рішенням Вищої кваліфікаційної комісії суддів України від 02 листопада 2016 р. № 141/зn-16. Офіційний сайт Вищої кваліфікаційної комісї̈ суддів України. URL: https: / / vkksu.gov.ua/ userfiles / doc/provedennia_konkursu.pdf (дата звернення: 27.08.2020).

8. Оголошено конкурс на зайняття вакантних посад суддів апеляиійних судів. Офіційний сайт Вищої кваліфікаційної комісії суддів України. URL: https: / / vkksu.gov.ua/ua/news / ogoloshienokonkurs-na-zajniattia-wakantnich-posadsuddiw-apieliaciinich-sudiw) (Jаma звернення: 27.08.2020).

9. Про Вищу раду правосуддя : Закон України від 21 грудня 2016 р. № 1798-VIII / Верховна Рада України. Голос України. 04 січня 2017 р. № 1.

10. Регламент Вищої ради правосуддя: затв. рішенням Вишої ради правосуддя від 24 січня 2017 р. № 52/0/15-17. Офіщійний сайт Вищої ради правосуддя. URL: https: / / hcj.gov.ua/sites / default / files/reglament_zminy_21.07.2020_0.doc (дата звернення: 14.08.2020). 